\title{
An Investigation of Extracurricular Activities in Relation to Sense of Identity of College Freshmen
}

\author{
John W. Lounsbury, John D. Richardson, Richard A. Saudargas, and Jacob J. Levy
}

Based on a sample of 330 freshman students enrolled in a First-Year Studies Program, 32 of 38 extracurricular activities of students were found to be significantly related to sense of identity, including those pertaining to socializing, religious/spiritual activities, leisure pursuits, study groups, volunteering, sports, traveling, and passive entertainment. Discussion of results includes an explanation for the findings as well as theoretical and practical implications.

This paper addresses the relationship between personal activities, extracurricular involvements, and leisure experiences in relation to sense of identity of college freshmen. Establishing a sense of identity is a crucial developmental task for individuals in the transition from adolescence to adulthood (Erikson, 1980) and is considered a prerequisite for adult adjustment and healthy engagement in major life roles such as employment, marriage, and parenting (Erikson, 1980; Muuss, 1996). For many individuals, college plays a unique and crucial role in identity formation (Nakkula, 2003) and is often the place where identity issues are resolved and the foundation for adult identity is established (Muuss, 1996). Indeed, in most theories of college student development, identity achievement is a crucial component, if not the ultimate stage or criterion of development. In their seminal work on college student development, Chickering and Reisser (1993) delineated seven key "vectors" or pathways of development of which establishing identity is superordinate to the other six.

There has been extensive theorizing about identity formation and empirical research on constructs related to identity achievement, such as personality traits (Clancy \& Dollinger, 1993), moral reasoning (Rowe \& Marcia, 1980), and life satisfaction (Lounsbury, Saudargas, Gibson, \& Leong, 2005). However, there has been surprisingly little research on what kinds of student extracurricular activities are related to identity achievement. There are important reasons for studying extracurricular, or out-of-class, activities. As reviewed by Kuh, Schuh, Whitt, \& Associates (1991), participation in extracurricular activities is positively related to:

John W. Lounsbury (jlounsbury@aol.com) and Richard A. Saudargas are professors, John D. Richardson (jricha30@utk.edu) is a doctoral student, and Jacob J. Levy is an assistant professor, all in the Department of Psychology at the University of Tennessee, Knoxville. 
social integration and institutional commitment; satisfaction with social life, major, and living arrangement; likelihood of graduation; development of leadership skills; and post-college success, including income. Also, unlike psychological constructs, such as openness and conscientiousness, extracurricular activities represent tangible behaviors that can be used by college student affairs practitioners, administrators, and other professionals working in college student development to guide practices, policies, programs, interventions, and other efforts designed to enhance the well-being, conduct, and growth of college students. For example, it would be easier for an adviser working with an apathetic and unmotivated freshman to suggest that the student consider joining a campus organization or interest group, meeting with a faculty member outside of class, or becoming involved in community service work than it would be for the adviser to try to increase the student's levels of, say, conscientiousness or openness.

Many different kinds of extracurricular activities have been proposed to help promote identity formation, including career planning (Raskin, 1989) and dating (Dreyer, 1994) as well as having and romantic and sexual relationships (McConnell, 1994). Other suggestions have included friendships with other students (Chickering \& Reisser, 1993), going to church (Dreyer, 1994), involvement in religion (Chickering \& Reisser, 1993), participating in student government (ibid), socializing with peers (ibid), and volunteering (Hamrick, Evans \& Schuh, 2002). However, with the exception of one recent study showing a positive relationship between prosocial behavioral tendencies of identity achieved university students (Hardy \& Kisling, 2006), there is a shortage of empirical research that links identity achievement to particular behaviors or activities for college students.

The present study was conducted to help address this lacuna. We wanted to ascertain whether identity achievement is related to a relatively wide range of different student activities, including extracurricular, leisure, recreational, and personal activities and involvements outside the classroom. As noted by Astin (1977) with regard to patterns of college student behavior, one could consider "an almost infinite range of phenomena," and it is infeasible to study an exhaustive set of activities. Our strategy was to study activities which represented some of the main categories presented in Astin's (1993) patterns of behavior, Pace and Kuh's (1998) College Student Experiences Questionnaire, and activities which Chickering and Reisser (1993) listed in their descriptions of the six vectors other than establishing identity.

The main research question addressed by our study was to determine if there were significant relationships between the individual extracurricular activities (listed in Table 1) and sense of identity for freshman. A positive correlation was expected for all activities except those reflecting spending time with friends from high school, spending time with family (as they represent a lack of movement toward individuation and establishing personal identity), and passive leisure activities such was watching television or listening to music. Following Jaffe's (1998) two basic dimensions of identity, we grouped activities into personal and social categories. Based on the importance of social/interpersonal relationships 
attributed to identity achievement by many theorists (e.g, Erikson, 1980;

Chickering \& Reisser, 1993), we expected that the magnitude of relationship would be larger for correlations involving social, interpersonal, or organizational activities than for correlations involving personal activities such as reading, using the Internet, praying, traveling out of state, drinking, or attending cultural events.

\section{Method}

\section{Participants}

The sample study included 330 Freshmen students enrolled in a First-Year Studies program at a large southeastern (U.S.) university, of which $68 \%$ were female (32\% male); $81 \%$ were Caucasian, 13\%--African-American, $2 \%$--Hispanic, $2 \%$--Asian, and 2\%--other. Ninety-one percent of the participants were in the 18-19 year-old age group; 12\%--20-25; and 6\% over 25.

\section{Procedure}

After obtaining human subjects approval from the university's Institutional Review Board, participants were solicited to take a personality inventory online. Immediately after completing the inventory, participants were provided a feedback report summarizing their personality characteristics and implications, including area of study, social life, managing stress, study habits, living situation, roommate preference, and using campus resources.

\section{Measures}

Sense of Identity. The Sense of Identity scale, which is part of Lounsbury and Gibson's (2005) Transition-to-College Inventory, was used in this study. The Sense of Identity scale has been found to be positively related to collegiate academic performance (Lounsbury, Huffstetler, Leong, \& Gibson, 2005) and collegiate life satisfaction (Lounsbury, Saudargas, Gibson, \& Leong, 2005), as well as negatively related to intention to withdraw from college (Lounsbury, Saudargas, \& Gibson, 2004). The Sense of Identity scale also correlates highly $(r=.80, p<.01)$ with Bennion and Adam's (1986) Identity Achievement subscale. The eight items in the Sense of Identity scale ask the respondent about having a definite sense of purpose in life, knowing what one wants out of life, having a set of basic beliefs and values that guide one's actions and decisions, having a clear set of personal values or moral standards, and having goals for the future. Responses for each item were made on a five-point Likert scale: $1=$ Strongly Disagree; $2=$ Disagree; $3=$ Neutral/Undecided; $4=$ Agree; $5=$ Strongly Agree. The coefficient alpha for the Sense of Identity Scale was .87 .

Activities. A total of 38 activities (see Table 1) were assessed, including extracurricular activities; leisure and recreation; social and interpersonal 
relationships; participation in advising, orientation, working, and study groups as well as whether or not the student lived at home. Most items were assessed on a five-point frequency of participation scale with these response choices: $1=$ Never, 2=Rarely, 3=Sometimes, 4=Often, 5=Very Often or All the Time.

\section{Results}

Correlations between the activities and Sense of Identity are presented in Table 1. All but six of the 38 correlations were significant at the $p<.05$ level. The higher magnitude correlations involved activities representing spending a lot of time talking to other people $(r=.65, p<.01)$; reading books on different subjects $(r=.58, p<.01)$; praying, meditating, and spiritual activities $(\mathrm{r}=.36, p<.01)$; going to church, synagogue, mosque, or a religious event $(r=.34, p<.01)$; interacting with a professor outside of class $(r=.29, p<.01)$; using the Internet for research or practical purposes $(r=.27, p<.01)$; setting learning goals $(r=.24, p<.01)$; socializing with friends $(r=.23, p<.01)$; taking road trips with friends $(r=.23, p<.01)$; spending time with family $(r=.22, p<.01)$; being in a serious romantic relationship $(r=.21, p$ $<.01)$; listening to music $(r=.20, p<.01)$; and attending a formal lecture, debate, or talk $(r=.20, p<.01)$. The median correlation for the 16 activities grouped as social and the median correlation for the 22 activities grouped as personal or individual were nearly the same-- $r=.15$ and $r=.16$, respectively.

\section{Discussion}

The present findings indicate that there are multiple linkages between students' extracurricular activities and sense of identity. Our results are generally consistent with reviews of the literature (e.g., Feldman \& Newcomb, 1970) and national studies involving large, diverse samples of colleges and students (Astin, 1993) which find many different types of activities important for student growth and development. In the context of the present results, there may be many pathways for college students to achieve a sense of identity.

Several of the individual correlations are consonant with Chickering and Reisser's vectors of student development. For example, participating in student government and other organizations align with their vectors labeled Integrity and Moving toward Interdependence. Also, the correlations involving religion, prayer, and spirituality correspond to Chickering and Reisser's Integrity vector. It is interesting to note that Astin (1971) found that "Religiousness" was a key factor involved in student behavioral change during college. It may be that identity formation results from increased religiosity during college.

One noticeable pattern of results was the relatively high frequency of significant correlations pertaining to social interaction. Twelve of the 16 correlations in this category were significant, with the higher magnitude correlations denoting interacting with friends and other students in different contexts as well as professors, advisers, and partners in Big Brothers/Big Sisters or 
other mentoring relationships. These results are consistent with most theories of identity development, such as Muuss (1996) who avers that identity can only be achieved through interaction with other people such as friends peers, and significant others.

A number of significant correlations for activities grouped in the personal category can be related to Chickering and Reisser's (1993) vectors. Setting learning goals reflects their Developing Competence vector, and going to church, synagogue, or mosque corresponds to their Developing Integrity vector. However, several activities in this group do not fit neatly into one single vector in Chickering and Reisser's model or any other classification of student activities we could find in the extant literature on college student affairs or development. An important goal for future efforts in this area would be to develop a coherent taxonomy of student activities or experiences that could be used by college student development researchers.

The negative correlation for spending time with friends from high school is consistent with theories of adolescent identity development which maintain that adolescents must separate from their peers (Muuss, 1996), though the positive correlation for spending time with family is not consistent with those same theories which also contend that adolescents must separate from their families to achieve identity.

Many of the items represented by the significant correlations could be classified as leisure activities; that is, freely chosen activities that one chooses to do in one's free time (Parker, 1983). Leisure activities offer college students excellent opportunities for the establishment of identity, because, when participating in leisure, students can try out behaviors and self-presentations which can lead to a variety of personally fulfilling consequences (e.g., acceptance, recognition, and positive feedback) that can, in turn, lead to identity achievement (cf. Kelly, 1983). Future efforts to develop a comprehensive measure of extracurricular activities or experiences for college student development could look to taxonomies of leisure activities such as the Leisure Activities Blank (LAB) (e.g., McKechnie, 1975) or the Leisure Interest Questionnaire (Hansen \& Scullard, 2002). In fact, several of the activities which were found here to be related to sense of identity correspond to the "Slow Living" and "Intellectual" factors in the LAB and to the "Socializing" and "Cultural Arts" scales of the Leisure Interest Questionnaire.

Taken as a whole, the present findings indicate that there may be many different activities that are related to students achieving a sense of identity. While correlations between activities and identity do not establish a direct causal connection, these findings are consistent with Hamrick et al.'s (2002) view that the college experience may offer "many opportunities for students to develop, among other things, personal and professional identity..." (p. 135). Similarly, there may be great potential for professionals working in the area of college student services to develop programs, policies, and activities designed to facilitate student identity achievement. 
Astin, A. W. (1977). Four critical years: Effects of college on beliefs, attitudes, and knowledge. San Francisco: Jossey-Bass.

Astin, A. W. (1993). What matters most in college? Four critical years revisited. San Francisco: Jossey-Bass.

Bennion, L. D. \& Adams, G. R. (1986). A revision of the extended version of the Objective Measure of Ego Identity Status: An identity instrument for use with late adolescents. Journal of Adolescent Research, 1(2), 183-197.

Chickering, A. W., \& Reisser, L. (1993). Education and identity. San Francisco: Jossey-Bass.

Clancy, S. M. \& Dollinger, S. J. (1993). Identity, self, and personality: Identity status and the five-factor model of personality. Journal of Research on Adolescence, 3(3), 227-245.

Dreyer, P. H. (1994). Designing curricular identity interventions for secondary schools. In S. L. Archer (Ed.), Interventions for adolescent identity development (pp. 121-140). Thousand Oaks, CA: Sage.

Erikson, E. H. (1980). Identity and the life cycle. New York: Norton.

Feldman, K. M. \& Newcomb, T. M. (1970). The impact of college on students. Volume 1. San Francisco, CA: Jossey-Bass.

Hamrick, F. A, Evans, N. J., and Schuh, J. H. (2002). Foundations of student affairs practice. San Francisco: Jossey-Bass.

Hansen, J. C. \& Scullard, M. G. (2002). Psychometric evidence for the leisure interest questionnaire and analyses of the structure of leisure interests. Journal of Counseling Psychology, 49 (3), 331-341.

Hardy, S. A. \& Kisling, J. W. (2006). Identity statuses and prosocial behaviors in young adulthood: A brief report. Identity, 6, 363-369.

Jaffe, M. L. (1998). Adolescence. New York: Wiley.

Kelly, J. R. (1983). Leisure identities and interactions. London: George Allen.

Kroger, J. (1996). Identity in adolescence. 2nd Ed. London: Routledge.

Kuh, G. D., Schuh, J. H., Whitt, E. J., \& Associates. (1991). Involving colleges. San Francisco: Jossey-Bass.

Lounsbury, J. W. \& Gibson, L. W. (2005). Technical manual for the Resource Associates Personal Style Inventory and Adolescent Personal Style Inventory. Knoxville, Tennessee: Resource Associates.

Lounsbury, J. W., Huffstetler, B. C., Leong, F. T., \& Gibson, L. W. (2005). Sense of identity and collegiate academic achievement. Journal of College Student Development.

Lounsbury, J. W., Hutchens, T., \& Loveland, J. (2005). An investigation of Big Five personality traits and career decidedness among early and middle adolescents. Journal of Career Assessment.

Lounsbury, J. W., Saudargas, R. A., \& Gibson, L. W. (2004). An investigation of Big Five and narrow personality traits in relation to intention to withdraw from college. Journal of College Student Development, 45(5), 517-534.

Lounsbury J. W., Saudargas, R. A., Gibson, L. W., \& Leong, F. T. (2005). An investigation of broad and narrow personality traits in relation to general and 
domain-specific life satisfaction of college students. Research in Higher Education, 46(6), 707-729.

McConnell, J. H. (1994). Lesbian and gay male identities as paradigms.

Interventions for adolescent identity development. In S. L. Archer Interventions for adolescent identity development (pp. 103-118). Thousand Oaks, CA: Sage Publications, Inc.

McKechnie, G. E. (1975). Manual for the Leisure Activities Blank. Palo Alto, CA: Consulting Psychologists Press.

Muuss, R.E. (1996). Theories of adolescence. New York: McGraw Hill.

Nakkula, M. (2003). Identity and possibility. In M. Sadowski (Ed.) Adolescents at school: Perspectives on youth, identity, and education. (7-18). Cambridge, Massachusetts: Harvard.

Pace, R. C. \& Kuh, G. D. (1998). College student experiences questionnaire. Bloomington, IN: Indiana University.

Parker, S. (1983). Leisure and work. London: Allen \& Unwin.

Raskin, P. M. (1989). Identity status research: Implications for career counseling. Journal of Adolescence, 12, 375-388.

Rowe, F. A. \& Waters, M. L. (1992). Can personality-type instruments profile majors in management programs? Journal of Education for Business, 68(1), $10-14$. 


\section{Correlations between Extracurricular Activity and Sense of Identity}

Activity

Correlation

Social/Interpersonal

1. Participated in study groups.

$.17^{* *}$

2. Socialized/hung out with friends.

$.23^{* *}$

3. Spent a lot of time talking to other people.

$.65^{* *}$

4. Spent time with friends from high school.

$-.16^{* *}$

5. Socialized/hung out with International students or students of

$.15^{* *}$ different ethnic group than mine.

6. Participated in student clubs or organizations.

7. Participated in student government.

8. Participated in a political campaign.

.05

9. Met/talked with a professor or instructor outside of class.

10. Spent time with my family (e.g., parents, siblings).

11. Met with adviser in last 6 months.

12. Member of a fraternity or sorority.

13. Served as Big Brother/Sister or mentored someone younger.

14. Been in a serious, romantic relationship.

15. Been in a sexual relationship.

16. Taken road trips with friends.

Personal

17. Set learning goals.

18. Attended orientation.

19. Living at home.

20. Traveled out of state.

21. Used the Internet for research or practical purpose.

22. Used the Internet or surfed the Web for fun, amusement, or personal recreation.

23. Read books on different subjects.

24. Attended a musical concert.

25. Drank alcohol.

26. Watched television or videos.

27. Gone to movies.

28. Listened to music on radio, stereo, CD's, IPOD, or other device. $.20^{* *}$

29. Played sports (e.g., intramural or pickup or alone). 
30. Engaged in outdoor recreation/sports (such as hiking, skiing, fishing).

31. Gone to church, synagogue, mosque, or religious event.

32. Prayed, meditated, or engaged in spiritual activity. $36^{* *}$

33. Visited a museum or art exhibit or cultural event. $10^{*}$

34. Attended a formal lecture, debate, talk, or speech. $.20^{* *}$

35. Participated in counseling or psychotherapy. $-.13^{*}$

36. Participated in career planning/exploration activity or program. $\quad .06$

37. Performed volunteer or community service work. .14*

38. Worked more than 20 hours/week. -.04 